\title{
MODELS OF AIRMEN'S AVIATION ACTIVITIES CYCLES IN THE TACTICAL AIRCRAFT'S OPERATING SYSTEM
}

\author{
MODELE CYKLI CZYNNOŚCI LOTNICZYCH \\ PILOTÓW W SYSTEMIE UŻYTKOWANIA \\ SAMOLOTÓW LOTNICTWA TAKTYCZNEGO
}

\author{
Emil Augustyn, Adam Kadziński
}

Poznań University of Technology, Faculty of Machines and Transport Politechnika Poznańska, Wydział Maszyn Roboczych i Transportu

\begin{abstract}
The tactical aircraft's operating system (system of a tactical aircraft's operational usage) constitutes the main research area of this paper. The authors consider and look into the airmen's aviation activities cycles which could be the basis for a clear and coherent indication and description of analyses domains for risk management's processes in the tactical aircraft's operating systems (TAOS). The first part of this paper presents the model of airman's aviation activities cycle $(A A A C)$ which indicates individual airman-aircraft relations during the realization an aircraft's operator activities that allow to execute air missions. There is also indicated the relationship between the $A A A C$ and the aircraft's operating cycle (cycle of an aircraft's operational usage). The second part of this paper presents the model of the series of airmen's aviation activities cycles (SAAAC) that integrates, among others: models of AAAC, the process of daily air missions' organizational and technical summary, the process of flight organization's and air training effects periodic summary.
\end{abstract}

Keywords: air task, flight, air mission, model of airman's aviation activities cycle, model of the series of airmen's aviation activities cycles

Streszczenie: Obszarem zainteresowań badawczych artykutu jest system użytkowania samolotów lotnictwa taktycznego. Rozpatrywane sa cykle czynności lotniczych pilotów, które moga być podstawa klarownego określania domen analiz dla procesów zarzadzaniu ryzykiem zagrożeń w systemach użytkowania samolotów lotnictwa taktycznego (SUżSLT). W pierwszej cześsi artykutu przedstawiono model cyklu czynności lotniczych pilota (CCLP) wskazujący na indywidualne relacje pilota z samolotem podczas wykonywania czynności operatorskich pozwalajacych realizować misje lotnicze. Wskazano również na zwiazek CCLP z cyklem użytkowania samolotu. Druga części artykutu poświęcona jest prezentacji modelu serii cykli czynności lotniczych pilotów (SCCLP) integrujacego m.in.: modele CCLP, proces podsumowań organizacyjno-specjalistycznych oraz proces podsumowania organizacji lotów i szkolenia lotniczego.

Stowa kluczowe: zadanie lotnicze, lot, misja lotnicza, model cyklu czynności lotniczych pilota, model serii cykli czynności lotniczych pilota 
Models of airmen's aviation activities cycles in the tactical aircraft's operating... Modele cykli czynności lotniczych pilotów w systemie użytkowania samolotów...

\section{Introduction}

It is commonly known that the aircraft operation [1, 13-15] whose origins date back to the first Wright brothers' flight, has been being an inseparable part of the modern societies' life. In December 1903 on the fields of Kitty Hawk in North Carolina rather no one was thinking about theoretical issues concerned the aircraft operation. Then it was only significant to simply get into the air, but in present times it is easy to notice how the issues related to the aircraft operation gain the meaning. On the other hand it causes a kind of evolution of basic aircraft operation systems' components i.e. aircraft's operating system (system of aircraft's operational usage) and aircraft's maintenance system both $[1,13,14,16]$. Parallel with this evolution, apart from its obvious advantages, there also occurs some of its disadvantages quite often associated with the used terms, names and definitions discrepancy. This kind of problem undoubtedly occurs e.g. in the tactical air force systems as a result of the implementation of various international NATO allied documents and regulations which contain divergent definitions of used terms and names. This state of affairs is a result of the lack of proper control over the applied nomenclature by one designated authority, as well as it is often caused by incorrect translation to Polish of foreign-language documents. Therefore it is justifiable to make attempts to order and undertake unambiguous and coherent description of the terms and names used in the tactical air force systems.

The main purpose of the following paper is to present models of the airmen's aviation activities cycles in connection with aircraft's operating cycles (cycle of aircraft's operational usage) within the Tactical Aircraft's Operating System (TAOS) [1] (system of tactical aircraft's operational usage) on the basis of allembracing expertise and current state of affairs concerning the Polish Tactical Air Force (PTAF). The following models mainly constitute kind of primary background to the formal ordering the nomenclature used in the TAOS which is the integral part of Tactical Aircraft Operation System in the Tactical Air Force System (TAFS) [1]. The presented models order on the timeline the specific parts, stages and phases of the cycles which covering a numerous processes and their operations, as well as cycles' events that occur in the TAOS.

\section{Tactical Aircraft's Operating System (TAOS) - overview}

The man as an user of the aircraft can fulfill different roles, i.e. as a pilot-incommand, a co-pilot, a passenger or a cabin crew member [4]. However, having analysed the aircraft's operating, there is usually considered the relationship between the crew (airman) and the aircraft who operate together in a given environment - an operational environment [13-16]. The aforementioned relationship acquires special significance, if it is considered within the tactical air force $[1,19,24]$ which is one of the types of military aviation. It is generally related to the fact that within this type of aviation there is an individualized contact between the crew (airman) and the military aircraft [5] - a tactical air force combat aircraft (e.g. multirole fighters, fighters or fighter-bombers). 
Using the term of the aircraft's crew, due to the specificity of tactical air force, the authors of this paper mainly refer to the single-person crew (only one airman). Notwithstanding of this fact, in some cases there may be a double-person aircraft's crew what is generally quite rare. What is more, there are neither passengers nor cabin crew. In the further considerations, the authors pointing to the "aircraft's crew", they are using the term of "airman", because of mainly one-person tactical aircraft's crew composition and the essential meaning of the term "crew".

The Model of Tactical Air Force System (MTAFS) which was presented in [1] constitutes a kind of new comprehensive approach to structure of one of the systems which functioning in the air force. The MTAFS consists of five decomposition levels which present the Tactical Air Force System (level 1) from the level of Tactical Air Wings (TAWs) with subordinate Tactical Air Force Bases (TAFBs) as organizational level (level 2), through the level of Tactical Aircraft Operation Systems (level 3) to the levels of a single tactical aircraft (level 4) and its components (level 5). What is more, the MTAFS also includes characteristic features (variables and parameters) of this system. The MTAFS reflects the PTAF via the structure in which tactical aircraft as technical objects $[2,18]$ constitute the dominant elements.

The level 3 of MTAFS (Fig. 1) concerns the Tactical Aircraft Operation Systems. This level of MTAFS decomposition presents the general and model scheme of tactical aircraft operation on the basis of complex analyses of the aircraft operation state of affairs [18] in the TAFBs. The tactical aircraft operation follows a complex operation process $[14,15]$ in a predefined operation system $[1,15]$ which mainly consists of two phases [14-16] - operating (usage) and maintenance. According to the analyzed literature [3] there is also a third phase - standby. It means an aircraft's readiness for duty or immediate deployment, but this aircraft is still in care of military Aerospace Engineering Staff (AES) [5] responsible for the maintenance. Due to that and having analyzed the present aircraft operation state of affairs in the TAFBs, the standby phase is included by the authors into the maintenance phase. Both aircraft operation phases have been comprehensively and extensively described in $[1,13-15]$.

The aircraft's operating (aircraft's operational usage) in the TAFB takes place directly in the Tactical Flying Squadrons (TFSQs) [1] which operate as a structural part of the Flying Operations Group (FOG) [1]. The military flying staff [4] (airmen) from the FOG/TFSQs with the airworthy aircraft or aircraft airworthy with restrictions constitute main elements of the TAOS. The Tactical Aircraft's Maintenance System (TAMS) [1] mainly consists of not airworthy aircraft or aircraft airworthy with restrictions and military AES divided into maintenance squadrons. The maintenance squadrons - the Aircraft Flightline Maintenance Squadrons (AFMSQs) and the Aircraft Technical Repair Squadrons (ATRSQs) [1] - operate as a part of the Maintenance Operations Group (MOG) [1]. The TAMS and other systems in the TAFS environment are appointed to support the TAOS. That makes the TAOS the leading system among TAFS' structures [1]. 
Models of airmen's aviation activities cycles in the tactical aircraft's operating... Modele cykli czynności lotniczych pilotów w systemie użytkowania samolotów...

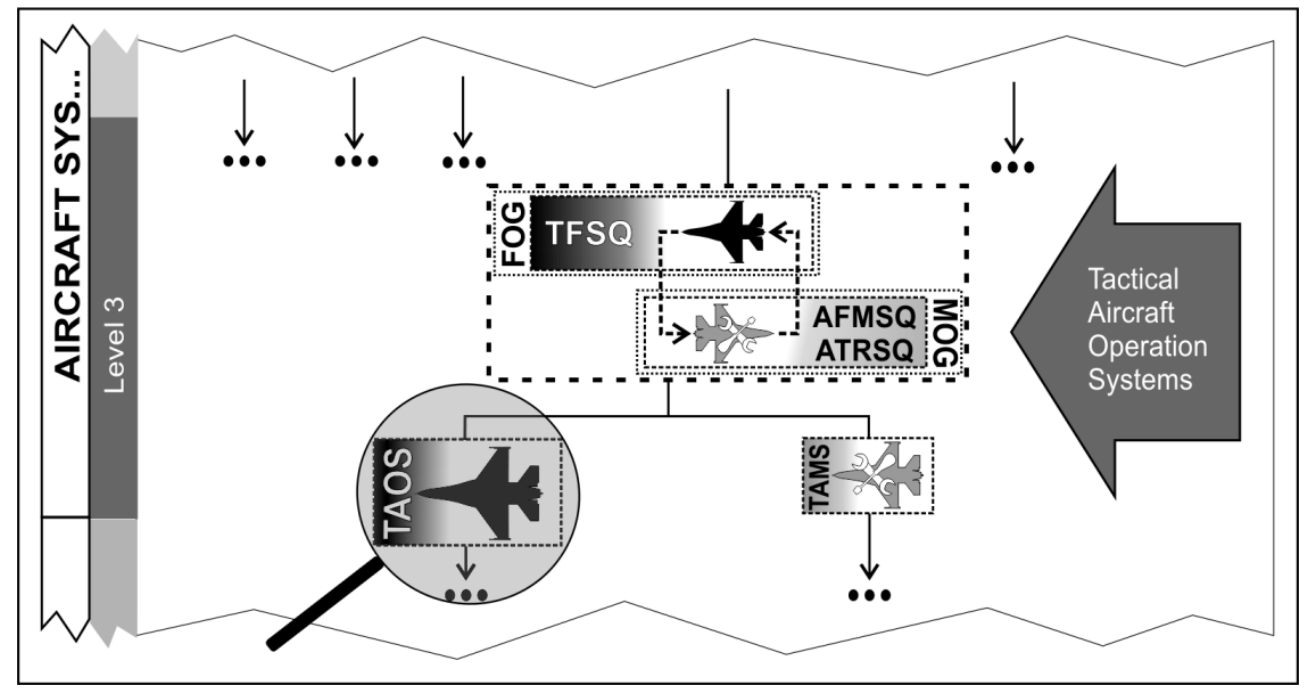

Fig. 1 Research area of the paper (used abbreviations are explained in the text) own scheme based on [1]

\section{Models of airmen's aviation activities cycles in the TAOS}

The aircraft's operating (aircraft's operational usage) in the TAOS is defined as an individualized relationship between the airman and the aircraft which consists in an aircraft operation by the airman as an operator (user), due to air mission (AM) execution. As a stage of the air mission the airman makes a flight whose most important phase is to perform the air task (AT). Performing the air tasks is the main goal of the TAOS. Due to perform the air task it is necessary to carry out a series of determined activities included into the airman's aviation activities cycle (AAAC) (Fig. 2).

The airman's aviation activities cycle consists of a lot of different elements, but from the viewpoint of the individualized airman and aircraft relationship, the aircraft's operating cycle (Fig. 2) is still the most essential there. The aircraft's operating cycle is proceeding during the air mission execution. Single AAAC consists of the following three parts (Fig. 2):

- (pre-) air mission(-s) preparations,

- air mission (coinciding with the aircraft's operating cycle),

- (post-) air mission(-s) summaries.

In order to highlight the time frame of the consecutive AAAC's elements (parts, stages, phases), the authors marked characteristic cycle's events in the figure 2 . It is assumed that the single AAAC begins with the event of general airman's introduction to planned air mission. It takes place during a check-in with the supervisor at the very beginning of the (pre-) air mission(-s) preparations. Then, airman familiarize with the flight schedule [6] or the flights organizer's order [6], which contains basic information about the planned air missions. 
The (pre-) air mission(-s) preparations consist of the following two processes:

- P1 - initial air mission preparation (planning),

- P2 - direct air mission preparation (information \& updating).

Both $\mathrm{P} 1$ and $\mathrm{P} 2$ processes include a series of operations and events that prepare the airman for the air mission execution. The (pre-) air mission(s) preparations time allows airman to develop the air mission's scenario that includes details necessary to perform the air task. The processes $\mathrm{P} 1$ and $\mathrm{P} 2$ have been described in detail in [6]. Times of both processes of the first part of the AAAC are as follows: P1 minimum 30 minutes; P2 $-1,5 \div 3$ hours. The presented time frame of P1 and P2 processes result from [6] and they are rather contractual. In fact, the (pre-) air mission(-s) preparations are carried out by airmen in a permanent and continuous manner and they often require to exceed the contractual time frame. The considered times of P1 and P2 processes mainly depend on airman's experience level and the complexity of the air task which is going to be performed as a part of the planned air mission. In addition, there are situations in which the airman does not begin the air mission execution immediately after the contractual time of the P2 process during the aviation work shift (Fig. 3). Then the airman is waiting for his/her turn and simultaneously take this time for further continuation of (pre-) air mission(-s) preparation. It is worthwhile to underline that after the first process (P1) of ACCC, it is acceptable to make a break before $\mathrm{P} 2$ process what is quite often practiced. This is due to the possibility of carrying out the P1 process on the working day that precede the day of air mission execution. However, the P2 process must be carried out on the day of air mission execution.

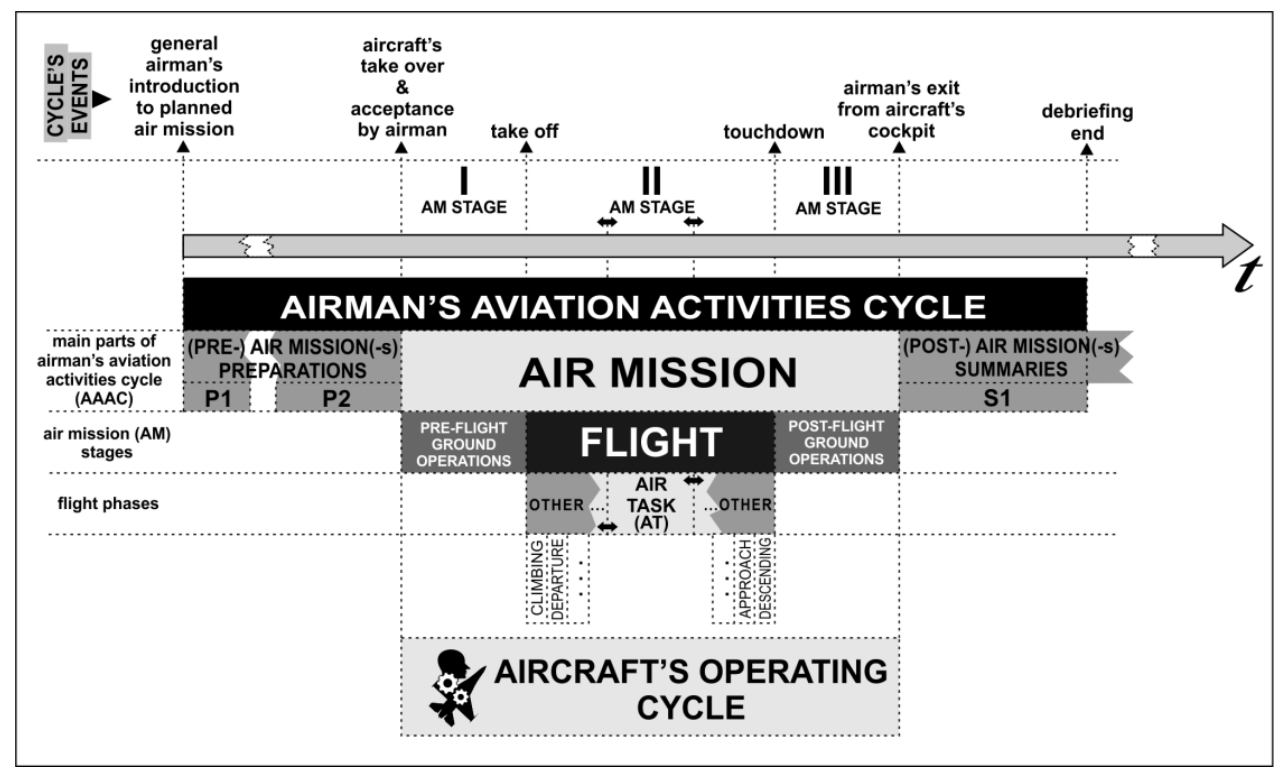

Fig. 2 Model of airman's aviation activities cycle-AAAC (used abbreviations are explained in the text) 
Models of airmen's aviation activities cycles in the tactical aircraft's operating... Modele cykli czynności lotniczych pilotów w systemie użytkowania samolotów...

The second part of the AAAC is an air mission which is often improperly equated with a flight and an air task. Having considered only of the meaning of the word "mission" [20], it has a much broader and overall meaning. In accordance with the presented concept/model, the air mission coincides with the time of the aircraft's operating cycle. What is more the air mission includes a flight and air task. In the following considerations it is assumed that the air mission begins after the event of aircraft's take over and acceptance by airman and follows after the completion of the part concerning the (pre-) air mission(-s) preparations (P1 and P2 processes). On the other hand, the event of airman's exit from aircraft's cockpit, after a power unit [9] and on-board systems shutdown, finishes the air mission part of AAAC.

The air mission consists of the following three basic stages (Fig. 2):

- pre-flight ground operations: from the event of aircraft's take over (from the AES) and acceptance by airman (aircraft's transfer from TAMS to TAOS), through the processes of power unit and on-board systems start-up with check, taxiing [10] before takeoff, takeoff preparations and takeoff roll [17] to the event of aircraft take off [17] (lift off) from the runway [11] surface,

- flight: consists of subsequent phases integrating many processes, operations and events which follow after the event of aircraft take off (lift off) from the runway surface until the event of its touchdown [17] on the runway surface,

- post-flight ground operations: they begin after the event of the aircraft touchdown on the runway surface, then such a following operations follow in sequence: landing roll [17], after landing taxiing (to the hangar or apron and aircraft stand [11]), power unit and on-board systems shutdown; the event of airman's exit from aircraft's cockpit finishes the third and the final stage of the air mission.

The flight stage as part of the air mission consists of several phases such as e.g.: climbing, departure, air task, approach, descending. These phases include a number of following processes e.g.: leaving (on departure) a (Military) Air Traffic Zone (MATZ) / (Military) Control Zone (MCTR) / (Military) Terminal Control Area (MTMA) [7], flight to Military Operations Area (MOA) [7, 22], air task performing in MOA, return to base (RTB) from MOA, approach to MTMA/MCTR/MATZ and landing approach [12].

The main phase of the flight stage is an air task. The air task contrary to many opinions is treated by the authors of this work as a component of the air mission. The air task as the main flight phase in figure 2 was presented in a characteristic way due to the obvious possibility of its duration variability. The air task duration depends on such variables and parameters as e.g.: the sort of the air mission, the type of air task, the aircraft refueling variant, the distance from the departure aerodrome to the MOA, etc. The mentioned duration variability may also applies the other (e.g. climbing, departure, approach) remaining flight phases (fig. 2), but the air task as the most important phase of the flight is susceptible to the influence of the largest number of variables and parameters. 
In the presented considerations having concerned the model of AAAC the authors basically focused on a single air mission which includes one flight when the air task is being performed. This kind of approach is used to present the model of AAAC and highlight that the main purpose of the following considerations is to order the nomenclature used in the air force (the tactical air force mainly). However, it should be noted that air missions in the tactical air force are often carried out by aircraft formations (minimum two-ship tactical formation - called as "element" which constitutes the basic combat unit employed by tactical aircraft) $[21,23]$. In such situations, the given aircraft formation usually executes one air mission, but each of airman performs assigned air task or tasks. The overall air mission result consists of all air tasks' performing results achieved by each airman who participate in this air mission. Besides of the air missions executed by the aircraft formation, there are also air missions being executed individually by the airman (one aircraft) when he/she can perform one or several air tasks during one flight.

The (post-) air mission(-s) summaries constitute the third part of AAAC. At this point it is justified to present a kind of broader view of several AAAC's environment and refer to the scheme (Fig. 3) which presents a series of airmen's aviation activities cycles (SAAAC). The SAAAC scheme (Fig. 3) implementation results from the fact that usually during the aviation work shift there is from 1 to $n_{c, k}$ number of AAAC carried out individually by each $k$-th airman from 1 to $a$ among set of airmen who take part in the aviation work shift.

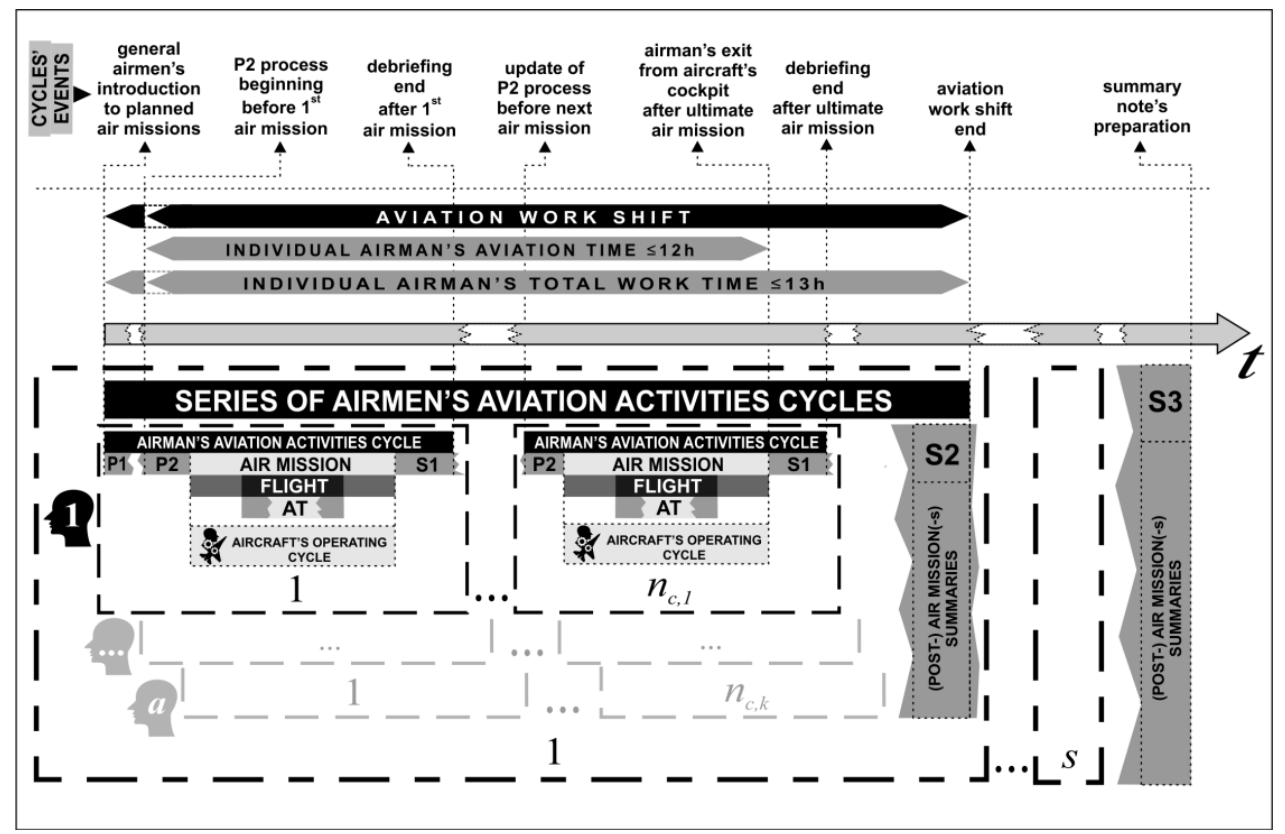

Fig. 3 Model of the series of airman's aviation activities cycles - SAAAC (used abbreviations and variables are explained in the text) 
Models of airmen's aviation activities cycles in the tactical aircraft's operating... Modele cykli czynności lotniczych pilotów w systemie użytkowania samolotów...

The (post-) air mission(-s) summaries consist of the following three processes:

- S1 - current air mission summary,

- S2 - daily air missions' organizational and technical summary,

- S3 - flight organization's and air training effects periodic summary.

However, they are not fully implemented in each AAAC. While the S1 process is implemented into the every single AAAC, in the case of S2 and S3 processes their implementation takes place respectively: $\mathrm{S} 2-$ at the end of every SAAAC, S3 - periodically after several finished SAAAC. Due to that, S2 and S3 processes are excluded from the model of single AAAC in the figure 2 . There is a possibility that SAAAC which consists of only one AAAC will be carried out during the aviation work shift. However, this is rare situation because the $k$-th $(k=1,2, \ldots, a)$ airman usually carries out more than one AAAC during the aviation work shift. In addition, the $\mathrm{S} 2$ process is implemented with the participation of each airmen from TAFB / FOG / TFSQ who carried out single AAAC during the aviation work shift. The S2 process is implemented only within the SAAAC if they are carried out on the basis of the flights schedule form and it is omitted when they are carried out on the basis of the flights organizer's order(-s) form. Each of the three types of (post-) air mission(-s) summaries indicated above is described in detail in paper [6]. The current air mission summary is a mandatory part of a single AAAC which determines the beginning of each subsequent AAAC. As a result of the debriefing carried out during the $\mathrm{S} 1$ process, the developed conclusions and recommendations must be taken into account during the next AAAC, already in its preparations' part ( $\mathrm{P} 1$ and $\mathrm{P} 2$ processes).

Once the first AAAC has been performed by the $k$-th airman, he/she no more implements the P1 process at the beginning of the next AAAC within the same aviation work shift. On the other hand, only selected operations of the $\mathrm{P} 2$ process are carried out then and they are mainly being updated in relation to the $\mathrm{P} 2$ process implemented during the first AAAC within the same aviation work shift. This kind of situation takes place in every subsequent AAAC numbered from the 2nd to the $n_{c, k}$ th which are carried out by the $k$-th airman. Several AAAC constitutes one SAAAC which usually ends with the $\mathrm{S} 2$ process closing the aviation work shift. The considered aviation work shift corresponds and equals to the SAAAC. What is more, it is often named as "aviation day" also. However, the term "aviation work shift" seems to be more accurate due to the possibility of performing SAAAC in different parts of the day.

The S3 process is implemented periodically after the end of the $s$-th SAAAC, but not less than once a month. This type of (post-) air mission(-s) summary applies to all SAAAC carried out in a given period of time and ends with the event of a summary note's preparation [6]. Usually only military functionaries, administrators, executives and commanders (not all airmen) from the TFSQ, FOG, TAFB $[1,8]$ take part in the $\mathrm{S} 3$ process.

The aviation work shift usually consists of more than one AAAC which may include more than one and various air missions. 
In the TAOS there is counted an individual $k$-th airman's aviation time from the beginning of the $\mathrm{P} 2$ process in the first AAAC of $k$-th $(k=1,2, \ldots, a)$ airman until the event of $k$-th airman's exit from aircraft' cockpit after the ultimate air mission in $n_{c, k}$-th AAAC during the aviation work shift. The individual $k$-th airman's aviation time can last up to 12 hours (taking into account the objections and points specified in [4]) while is maintaining the individual $k$-th airman's total work time which must not exceed of 13 hours. Within the individual airman's aviation time the following things are defined: maximum $k$-th airman's flight hours, maximum number of air missions that $k$-th airman can execute, breaks between subsequent air missions and AAAC. These aspects are specified in [4] and aviation training programs. According to [4], breaks between subsequent individual airman's aviation times should provide the required rest time. The rest time means a time off from work activities, between subsequent periods of the individual airman's aviation times of the $k$-th airman or subsequent periods of performing official duties. In the case of an airman who performs the operator's activities in the TAOS during SAAAC the minimum rest period is 11 hours.

\section{Conclusions}

The concept of negation the often-found equalization the terms of "air mission", "flight" and "air task" gives the possibility of a clear and coherent development of a set of basic terms related to the tactical aircraft's operating. Due to that the authors presents the following terms with their definitions.

Air mission is the main part of the airman's aviation activities cycle which includes a series of subsequent processes, operations and events from the event of the aircraft's take over and acceptance by airman until the event of airman's exit from aircraft's cockpit. Quite often occurs a situation when the same air mission is executed simultaneously by several airmen who are the operators of several aircraft and they form the formation. Such a situation usually results from the complexity of the planned air mission's scenario, which could require to make several flights simultaneously in order to perform the same or different air tasks by every airman from the formation.

Flight is the stage of an air mission covering the aircraft's movement in the airspace from the event of the aircraft's take off (lift off) from the runway surface until the event of its touchdown (its re-contact with the ground) on the runway surface.

Air task is the main phase of the flight and constitutes a set of specific and target airman's/airmen's actions during the flight within the set time and area, being performed to achieve the air mission's desired objectives such as: training, operational or combat. It is determined by the superior, instructor or formation leader and performed by the airman as an operator who operationally use the aircraft in the TAOS. 
Models of airmen's aviation activities cycles in the tactical aircraft's operating... Modele cykli czynności lotniczych pilotów w systemie użytkowania samolotów...

The having presented models apart from the terms', names' and definitions' systematization also fulfill the task of organizing subsequent parts, stages and phases of the AAAC and SAAAC which are continuously being carried out in the TAOS. They also indirectly indicate the periods of processes related to the aircraft's maintenance. The approach presented in this paper concerns the tactical air force that operates in the peacetime.

\section{Acknowledgements}

The research work financed with the means of statutory activities of Faculty of Machines and Transport Poznan University of Technology No. 05/52/DSPB/0280.

\section{References}

[1] Augustyn E., Kadziński A., Systemic approach and model of the Polish Tactical Air Force. Journal of KONES Powertrain and Transport, nr 24(2), 2017, p. 7-16, DOI: 10.5604/01.3001.0010.2889.

[2] Augustyn E., Kadziński A., Model of Generalized Technical System. Journal of Mechanical and Transport Engineering, nr 69(3), 2017, p. 5-13, DOI: 10.21008/j.2449-920X.2017.69.3.01.

[3] Borgoń J., Jaźwinski J., Niezawodnośc eksploatacyjna i bezpieczeństwo lotów, Wydawnictwo Komunikacji i Łączności, Warszawa 1989.

[4] Dowództwo Generalne Rodzajów Sił Zbrojnych (MON), Regulamin lotów lotnictwa Sił Zbrojnych Rzeczypospolitej Polskiej (RL-2016), Warszawa 2016.

[5] Dowództwo Generalne Rodzajów Sił Zbrojnych (MON), Instrukcja służby inżynieryjno-lotniczej lotnictwa Sił Zbrojnych Rzeczypospolitej Polskiej (ISIL2017), Warszawa 2017.

[6] Dowództwo Generalne Rodzajów Sił Zbrojnych (MON), Instrukcja organizacji lotów w lotnictwie Sił Zbrojnych Rzeczypozpolitej Polskiej (IOL-2016), Warszawa 2016.

[7] Dowództwo Generalne Rodzajów Sił Zbrojnych (MON), Instrukcja zarządzania ruchem lotniczym w Siłach Zbrojnych Rzeczypospolitej Polskiej (IZRL-2017), Warszawa 2017.

[8] Grenda B., Mróz P., Nowak J., Sławiński M., Dowodzenie siłami powietrznymi, Akademia Obrony Narodowej, Warszawa 2011.

[9] International Civil Aviation Organization, International Standards and Recommended Practices. Annex 8 to the Convention on International Civil Aviation - Airworthiness of Aircraft, 11th edition, 2010.

[10] International Civil Aviation Organization, International Standards. Annex 2 to the Convention on International Civil Aviation - Rules of the Air, 10th edition, 2005.

[11] International Civil Aviation Organization, International Standards and Recommended Practices. Annex 14 to the Convention on International Civil Aviation - Aerodromes, vol.1. Aerodrome Design and Operations, 5th edition, 2009. 
[12] International Civil Aviation Organization, Procedures of Air Navigation Services . Aircraft Operations (Doc 8168), vol. 1. Flight Procedures, 5th edition, 2006.

[13] Lewitowicz J., Eksploatacyjne własności i własciwości samolotów i śmigłowców, Instytut Techniczny Wojsk Lotniczych, Warszawa 2015.

[14] Lewitowicz J., Podstawy esploatacji statków powietrznych. Tom 1. Statek powietrzny i elementy teorii, Instytut Techniczny Wojsk Lotniczych, Warszawa 2001.

[15] Lewitowicz J., Podstawy eksploatacji statków powietrznych. Tom 3. Systemy eksploatacji statków powietrznych, Instytut Techniczny Wojsk Lotniczych, Warszawa 2006.

[16] Lewitowicz J., Żyluk A., Podstawy eksploatacji statków powietrznych. Tom 5. Techniczna eksploatacja statków powietrznych, Instytut Techniczny Wojsk Lotniczych, Warszawa 2009.

[17] Milkiewicz A., Praktyczna aerodynamika i mechanika lotu samolotu odrzutowego w tym wysokomanewrowego, Instytut Techniczny Wojsk Lotniczych, Warszawa 2009.

[18] Młyńczak M., Metodyka badań eksploatacyjnych obiektów mechanicznych, Oficyna Wydawnicza Politechniki Wrocławskiej, Wrocław 2012.

[19] NATO Standarization Agency, NATO Glossary of Terms and Definitions (AAP-6), Brussels 2014.

[20] Sobol E. (red. ., Słownik wyrazów obcych. Wydanie nowe, Wydawnictwo Naukowe PWN, Warszawa 1999.

[21] United States Air Force - Air Education and Training Command, AETC Tactics Techniques and Procedures 11-1 (AETCTTP 11-1). Employment Fundamentals T-38C - Introduction to Fighter Fundamentals (IFF), 2009.

[22] United States of America - Department of the Air Force, Air Force Manual 11-217, vol. 2 (AFMAN 11-217V2). Flying Operations - Visual Flight Procedures, 2010.

[23] United States of America - Department of the Air Force, Air Force Manual 11248 (AFMAN 11-248). Flying Operations - T6 Primary Flying, 2011.

[24] Zabłocki E., Siły powietrzne, Akademia Obrony Narodowej, Warszawa 2007.

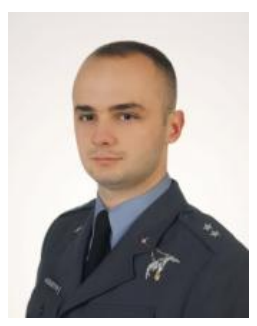

Emil Augustyn, PhD student at Poznan University of Technology, Faculty of Machines and Transport, graduated from the Polish Air Force Academy in 2015, specialization: transportation, reliability of military aircraft, military aviation safety and risk management, modeling and analysis of transport processes and systems (Share 60\%).

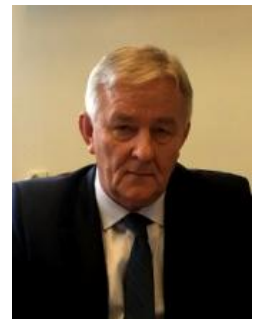

Prof. Adam Kadziński, Poznan University of Technology, Institute of Combustion Engines and Transport, specialization: railway transportation, reliability of railway vehicles, safety of railway transportation, risk management in transport, modeling and analysis of transport processes and systems (Share 40\%). 
Models of airmen's aviation activities cycles in the tactical aircraft's operating... Modele cykli czynności lotniczych pilotów w systemie użytkowania samolotów...

\section{MODELE CYKLI CZYNNOŚCI LOTNICZYCH PILOTÓW W SYSTEMIE UŻYTKOWANIA SAMOLOTÓW LOTNICTWA TAKTYCZNEGO}

\section{Wstęp}

Eksploatacja statków powietrznych [1, 13-15], której początki sięgają pierwszego lotu braci Wright, staje się nieodłączną częścią życia współczesnych społeczeństw. O ile w grudniu 1903 roku na polach Kitty Hawk w Karolinie Północnej nikt nie zastanawiał się nad zagadnieniami teoretycznymi eksploatacji statków powietrznych, a raczej nad tym żeby po prostu wzbić się w powietrze, o tyle w obecnych czasach widać jak bardzo zagadnienia związane z eksploatacją nabierają znaczenia. To zaś wywołuje ewolucję podstawowych składowych systemu eksploatacji statków powietrznych, tj. systemu użytkowania oraz systemu utrzymania $[1,13,14,16]$. Wraz z tą ewolucją, poza jej oczywistymi zaletami, pojawiają się również pewne negatywne aspekty związane często m.in. $\mathrm{z}$ rozbieżnością stosowanego nazewnictwa. Problem ten niewątpliwie występuje w systemach lotnictwa taktycznego, gdzie m.in. wskutek implementacji międzynarodowych dokumentów oraz regulacji sojuszniczych NATO, często pojawiają się rozbieżne definicje pojęć. Taki stan rzeczy wynika m.in. z braku właściwego zwierzchnictwa jednego wyznaczonego organu nad stosowaną nomenklaturą, a także często $\mathrm{z}$ niewłaściwego thumaczenia dokumentów obcojęzycznych. Uzasadnionym więc staje się podejmowanie prób porządkowania oraz jednoznacznego i koherentnego opisu stosowanych pojęć związanych z systemami lotnictwa taktycznego.

Celem niniejszej pracy jest zaprezentowanie modeli cykli czynności lotniczych pilotów w powiązaniu z cyklami użytkowania samolotów lotnictwa taktycznego w ramach Systemu Użytkowania Samolotów Lotnictwa Taktycznego (SUżSLT) na podstawie doświadczeń i stanu obecnego lotnictwa taktycznego Sił Powietrznych RP. Modele te stanowią przede wszystkim tho do formalnego uporządkowania nazewnictwa stosowanego w obszarze SUżSLT, będącego integralną częścią Systemu Eksploatacji Samolotów Lotnictwa Taktycznego w Systemie Lotnictwa Taktycznego (SLTkt) [1]. Opracowane modele m.in. porządkują na osi czasu określone części, etapy i fazy cykli obejmujących szereg procesów i ich operacji oraz zdarzeń jakie występują w ramach SUżSLT.

\section{System Użytkowania Samolotów Lotnictwa Taktycznego (SUżSLT)}

Człowiek jako użytkownik statku powietrznego może występować w różnych rolach, tj. jako pilot-dowódca, drugi pilot, pasażer, czy też członek personelu pokładowego [4]. Jednak analizując użytkowanie statku powietrznego zwykle rozpatrywana jest relacja załoga (pilot) - statek powietrzny operujący w określonym środowisku - otoczeniu eksploatacyjnym [13-16]. 
Ta relacja nabiera szczególnego znaczenia jeśli rozpatrywana jest w ramach lotnictwa taktycznego sił powietrznych $[1,19,24]$ stanowiącego jeden z rodzajów lotnictwa wojskowego. Związane jest to $\mathrm{z}$ faktem, iż $\mathrm{w}$ ramach tego rodzaju lotnictwa dochodzi do zindywidualizowanego kontaktu pomiędzy załogą (pilotem) i wojskowym statkiem powietrznym [5] - samolotem [9] lotnictwa taktycznego (np. wielozadaniowym, myśliwskim czy też myśliwsko-bombowym).

Operując określeniem załogi samolotu, ze względu na specyfikę lotnictwa taktycznego sił powietrznych, autorzy tej pracy mają na myśli głównie załogę jednoosobową (tylko jednego pilota). W niektórych przypadkach może występować załoga dwuosobowa. Nie występują tutaj ani pasażerowie, ani też personel pokładowy. W dalszych rozważaniach wskazując na „załogę samolotu” autorzy operują pojęciem ,pilot”, ze względu na jej - w przeważającej części jednoosobowy skład oraz clou znaczenia słowa ,załoga”.

Zaproponowany w pracy [1] Model Systemu Lotnictwa Taktycznego (MSLTkt) jest próbą kompleksowego spojrzenia na strukturę jednego z systemów (poziom 1) funkcjonujących $\mathrm{w}$ lotnictwie wojskowym, od poziomu organizacyjnego jaki stanowią skrzydła lotnictwa taktycznego (SLT) wraz z podległymi bazami lotnictwa taktycznego (BLT) (poziom 2), poprzez poziom eksploatacji samolotów lotnictwa taktycznego (poziom 3), aż do poziomu pojedynczego samolotu (poziom 4) i jego komponentów (poziom 5), z uwzględnieniem cech charakterystycznych (zmiennych decyzyjnych i parametrów) tego systemu. Model ten odwzorowuje lotnictwo taktyczne Sił Powietrznych RP w postaci struktury, w której elementami dominującymi są samoloty lotnictwa taktycznego jako obiekty techniczne $[2,18]$.

Poziom 3 (rys. 1) MSLTkt stanowią Systemy Eksploatacji Samolotów Lotnictwa Taktycznego. Poziom ten jest uproszczonym odwzorowaniem eksploatacji samolotów na podstawie analizy sytuacji eksploatacyjnej [18] w BLT. Eksploatacja samolotów w sensie ich działania odbywa się wg złożonego procesu eksploatacji $[14,15]$, w określonym systemie eksploatacji [1, 15], który integruje dwie fazy eksploatacyjne [14-16] - użytkowanie oraz utrzymanie. W literaturze przedmiotu [3] wskazuje się również na występowanie fazy dyżurowania samolotów. Ze względu na zasady eksploatacji samolotów w BLT, tę fazę można zakwalifikować do pozostawania samolotów w fazie utrzymania, gdyż zakłada się, że do momentu zdarzenia przyjęcia samolotu przez pilota znajduje się on pod „opieką” personelu technicznego Służby Inżynieryjno-Lotniczej (SIL) [5] odpowiadającego za proces utrzymania samolotów. Obie wskazane wcześniej fazy eksploatacyjne, adekwatnie do struktury modelu SLTkt, zostały szeroko opisane w pracach [1, 13-15]. 
Models of airmen's aviation activities cycles in the tactical aircraft's operating... Modele cykli czynności lotniczych pilotów w systemie użytkowania samolotów...

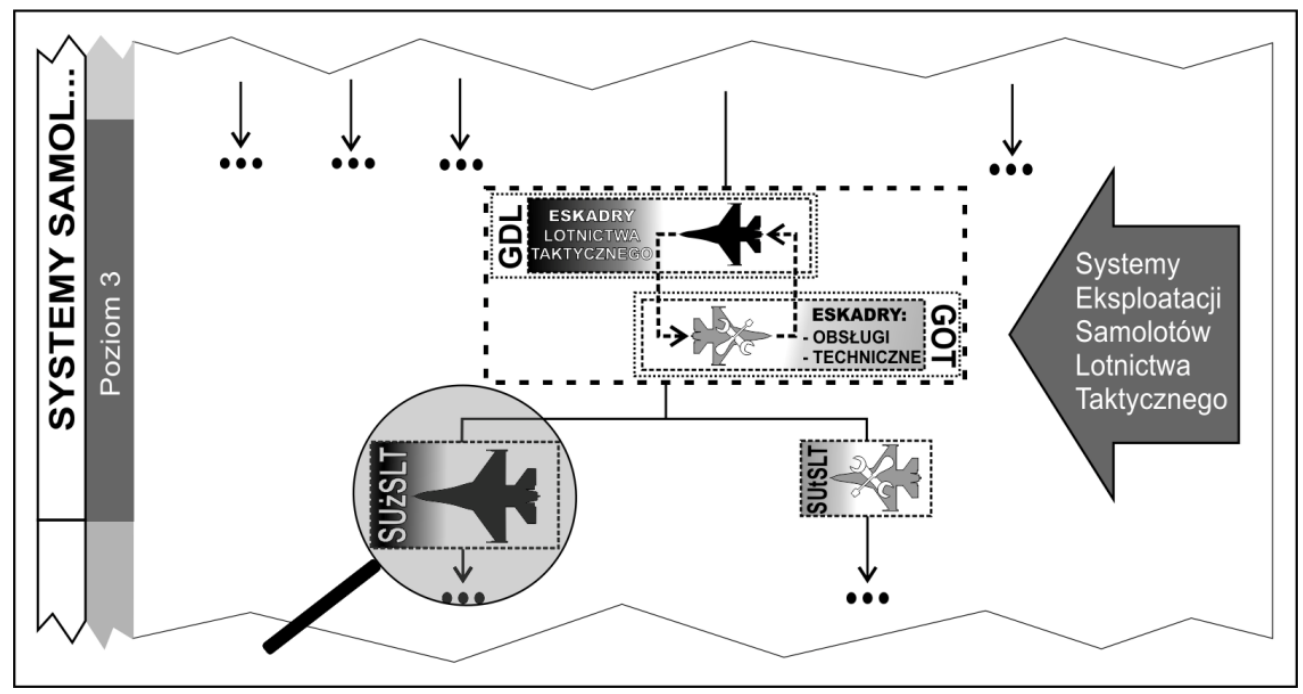

Rys. 4 Obszar zainteresowań badawczych artykulu (objaśnienia użytych skrótów znajduja się w tekście) - opracowanie wtasne na podstawie [1]

Użytkowanie samolotów w BLT odbywa się bezpośrednio w Eskadrach Lotnictwa Taktycznego (ELT) [1], które funkcjonują w ramach Grup Dzialań Lotniczych (GDL) [1]. Personel latający [4] (piloci) wraz z samolotami funkcjonującymi w GDL/ELT są podstawowymi elementami SUżSLT. W Systemie Utrzymania Samolotów Lotnictwa Taktycznego (SUtSLT) [1] występują samoloty w stanie niezdatności lub ograniczonej zdatności oraz personel SIL, który został podzielonym na Eskadry Obsługi (EO) oraz Eskadry Techniczne (ET) działające w ramach Grupy Obsługi Technicznej (GOT). System Utrzymania Samolotów Lotnictwa Taktycznego oraz pozostałe systemy z otoczenia SLTkt, są powoływane na potrzeby wsparcia SUżSLT. Czyni to SUżSLT wiodącym w strukturach SLTkt [1].

\section{Modele cykli czynności lotniczych pilotów w SUżSLT}

Użytkowanie samolotu w SUżSLT jest definiowane jako zindywidualizowana relacja pilota z samolotem, polegająca na wykonywaniu czynności operatorskich w celu realizacji misji lotniczej (ML). W ramach misji lotniczej pilot wykonuje lot, którego najważniejszą fazą jest realizacja zadania lotniczego (ZL). Realizacja zadań lotniczych stanowi zasadniczy cel funkcjonowania SUżSLT. Aby jednak zadanie lotnicze mogło zostać zrealizowane, zachodzi konieczność wykonywania szeregu czynności ujętych w cyklu czynności lotniczych pilota (CCLP) (rys. 2).

W skład cyklu czynności lotniczych pilota wchodzi wiele elementów, jednak z punktu widzenia zindywidualizowanej relacji pilota z samolotem, najważniejszy pozostaje cykl użytkowania samolotu (rys. 2) realizowany w czasie misji lotniczej. 
Pojedynczy CCLP składa się z trzech następujących części (rys. 2):

- przygotowania do misji lotniczych,

- misja lotnicza (pokrywająca się z cyklem użytkowania samolotu),

- podsumowania misji lotniczych.

Z uwagi na potrzebę wyróżnienia ram czasowych elementów (części, etapów, faz) CCLP, na rysunku 2 zaznaczono charakterystyczne zdarzenia cyklu. Przyjmuje się że pojedynczy CCLP rozpoczyna się od zdarzenia ogólnego zapoznania pilota z planowaną misją lotniczą, co ma miejsce podczas odprawy z przełożonym na samym początku przygotowań do misji lotniczej. Pilot zapoznaje się wtedy z planową tabela lotów [6] lub rozkazem organizatora lotów [6], w których zawarte są podstawowe informacje na temat planowanych misji lotniczych.

Przygotowania do misji lotniczych składają się z dwóch procesów:

- P1 - wstępne przygotowanie do misji lotniczej,

- P2 - bezpośrednie przygotowanie do misji lotniczej.

W ramach procesów P1 i P2 zachodzi szereg operacji i zdarzeń, które przygotowują pilota do wykonania misji lotniczej. Czas przygotowań pozwala pilotowi zbudować/opracować scenariusz misji lotniczej w ramach której będzie wykonane zadanie lotnicze. Procesy P1 i P2 zostały szczegółowo opisane w [6]. Oba procesy pierwszej części CCLP trwają odpowiednio: dla P1 - minimum 30 minut; dla P2 - 1,5 $\div 3$ godzin. Ramy czasowe procesów P1 i P2 wynikające z [6] są w pewnym sensie umowne. Tak naprawdę przygotowania do misji lotniczych realizowane są przez pilotów $\mathrm{w}$ sposób permanentny i często wymagają przekroczenia umownych ram czasowych. Czasy realizacji tych procesów zależą m.in. od poziomu doświadczenia pilota oraz stopnia trudności i złożoności zadania lotniczego wykonywanego w ramach planowanej misji lotniczej. Do tego dochodzą także sytuacje w których pilot nie rozpoczyna misji lotniczej tuż po upłynięciu umownego czasu procesu P2 podczas zmiany lotnej (rys. 3) i czeka na swoją kolej, wykorzystując ten czas do dalszego przygotowania. Warto jednak zaznaczyć, że już $w$ tej części CCLP, po zrealizowaniu procesu P1, dopuszcza się jej przerwanie i rozpoczęcie przerwy przed procesem P2. Wynika to z możliwości przeprowadzenia procesu P1 w dniu roboczym poprzedzającym realizację misji lotniczej. Proces P2 zawsze jednak musi zostać przeprowadzony w dniu realizacji misji lotniczej.

Drugą część CCLP stanowi misja lotnicza, która często jest utożsamiana z lotem oraz zadaniem lotniczym. Biorąc pod uwagę znaczenie samego słowa „misja” [20], to stanowi ono jednak znacznie szersze pojęcie i w myśl prezentowanej koncepcji pokrywa się z czasem właściwego użytkowania samolotu - cyklem użytkowania samolotu. Dla potrzeb rozważań przeprowadzanych w niniejszej pracy przyjęto, że misja lotnicza rozpoczyna się po zdarzeniu przyjęcia samolotu przez pilota, które następuje po zakończeniu części dotyczącej przygotowań do misji lotniczej (procesy P1 i P2). Natomiast za koniec misji lotniczej przyjmuje się zdarzenie opuszczenia kabiny samolotu przez pilota po wyłączeniu zespołu napędowego [10] i systemów pokładowych. 
Models of airmen's aviation activities cycles in the tactical aircraft's operating... Modele cykli czynności lotniczych pilotów w systemie użytkowania samolotów...

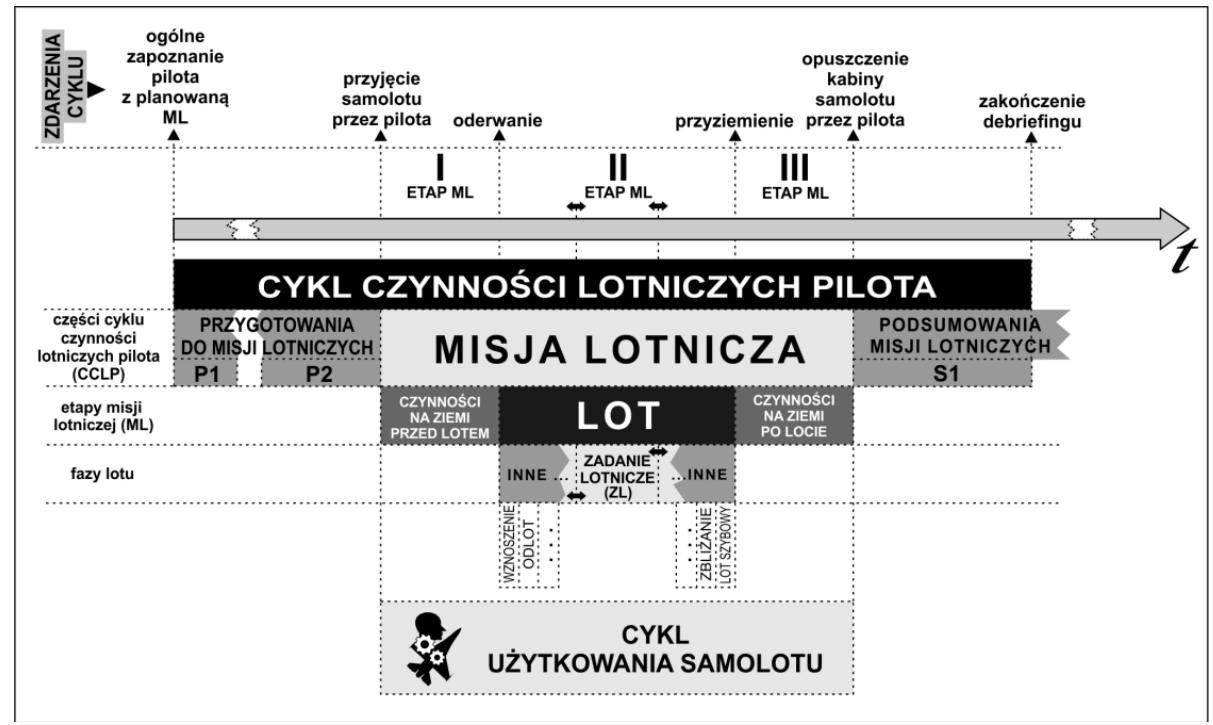

Rys. 5 Model cyklu czynności lotniczych pilota w SUżSLT (objaśnienia użytych skrótów znajdują się w tekście)

W ramach misji lotniczej można wyróżnić trzy zasadnicze etapy (rys. 2):

- czynności na ziemi przed lotem: od zdarzenia przyjęcia samolotu przez pilota od personelu SIL (transfer samolotu z SUtSLT do SUżSLT), poprzez procesy uruchomienia i sprawdzania, kołowania [9] przed startem, przygotowania do startu oraz startu do momentu zdarzenia oderwania [17] samolotu od nawierzchni drogi startowej [11] po zakończeniu operacji rozbiegu [17],

- lot: składa się z kolejnych faz integrujących wiele procesów, operacji i zdarzeń procesów następujących po zdarzeniu oderwania samolotu od nawierzchni drogi startowej do momentu zdarzenia przyziemienia [17] na drodze startowej,

- czynności na ziemi po locie: następują po zdarzeniu przyziemienia samolotu na drodze startowej, następnie dochodzi do operacji dobiegu [17] po czym następują procesy takie jak kołowanie po lądowaniu (do hangaru lub na płaszczyznę postoju samolotów / stanowisko postojowe [11]) oraz wyłączenie (zespołu napędowego i systemów pokładowych); czynności na ziemi po locie kończy zdarzenie opuszczenia kabiny samolotu przez pilota, które zamyka zarazem trzeci i ostatni etap misji lotniczej.

Etap lotu w ramach misji lotniczej składa się z kilku faz, pośród których wyróżnia się m.in. wznoszenie, odlot, zadanie lotnicze, zbliżanie, lot szybowy. Fazy te obejmują szereg procesów takich jak m.in.: odejście z (M)ATZ (Military Air Traffic Zone) / (M)CTR (Military Control Zone) / (M)TMA (Military Terminal Control Area), dolot do strefy działań MOA (Military Operations Area) [7, 22], realizacja zadania lotniczego w strefie działań MOA, powrót ze strefy działań MOA, zbliżanie do (M)TMA / (M)CTR / (M)ATZ oraz podejście do lądowania [12]. 
Główną fazą etapu lotu jest zadanie lotnicze. Zadanie lotnicze wbrew wielu opiniom, jest traktowane przez autorów tej pracy, jako składowa misji lotniczej. Zadanie lotnicze jako główna faza lotu, na rysunku 2 zostało zaprezentowane w charakterystyczny sposób ze względu na oczywistą możliwość zmienności czasu trwania tej fazy lotu. Czas realizacji zadania lotniczego uzależniony jest od takich zmiennych i parametrów jak m.in.: charakter misji lotniczej, rodzaj zadania lotniczego, wariant zatankowania samolotu, odległość strefy działań MOA od lotniska startu itd.. Wspomniana zmienność czasu trwania może również dotyczyć pozostałych faz lotu (inne - rys. 2), jednak zadanie lotnicze jako najważniejsza faza lotu jest podatna na wpływ największej liczby zmiennych i przyjmowanych parametrów.

W prezentowanych rozważaniach autorzy w modelu CCLP zasadniczo skupili się na pojedynczej misji lotniczej w ramach której podczas jednego lotu realizuje się jedno zadanie lotnicze. Takie podejście służy do przedstawienia modelowego CCLP oraz do podkreślenia że zasadniczy cel rozważań to uporządkowanie stosowanego nazewnictwa. Należy jednak zaznaczyć, iż w lotnictwie taktycznym misje lotnicze często realizowane są w ugrupowaniu/formacji samolotów (minimum dwa samoloty - para/element, która stanowi podstawową jednostkę bojową w lotnictwie taktycznym) [21, 23]. W takich sytuacjach dane ugrupowanie realizuje zazwyczaj jedną misję lotniczą, ale każdy z pilotów wykonuje swoje (przydzielone) zadanie lub zadania lotnicze. Wykonanie przez każdego pilota z ugrupowania zadania/zadań lotniczych składa się na ogólny wynik misji lotniczej. Poza realizacją misji lotniczej w ugrupowaniu/formacji, również podczas realizacji misji lotniczej indywidualnie przez pilota (jeden samolot), może on wykonywać jedno lub kilka zadań lotniczych podczas jednego lotu.

Trzecią część CCLP stanowią podsumowania misji lotniczych. W tym miejscu zasadnym staje się przedstawienie szerszego spojrzenia na środowisko wielu CCLP i odwołanie do schematu (rys. 3) prezentującego serię cykli czynności lotniczych pilotów (SCCLP). Zastosowanie kolejnego schematu (rys. 3) wynika m.in. z faktu, iż zazwyczaj realizuje się liczbę od 1 do $n_{c, k}$ CCLP indywidualnie przez każdego $k$-tego pilota, ze zbioru od 1 do $a$ pilotów, biorących udział w zmianie lotnej.

Podsumowania misji lotniczych składają się z trzech podstawowych procesów:

- S1 - podsumowanie bieżące,

- S2 - podsumowanie organizacyjno-specjalistyczne,

- S3 - podsumowanie organizacji lotów i szkolenia lotniczego.

Nie są one jednak realizowane w pełnym zestawieniu w każdym CCLP. O ile proces $\mathrm{S} 1$ jest realizowany $\mathrm{w}$ każdym pojedynczym CCLP, to w przypadku procesów S2 i S3 ich realizacja ma miejsce odpowiednio: S2 - na zakończenie każdej SCCLP, S3 - po zakończeniu kilku SCCLP. Na tej podstawie, na rysunku 2, procesy S2 i S3 zostały wyłączone $\mathrm{z}$ pojedynczego CCLP. Istnieje jednak możliwość, że podczas zmiany lotnej zostanie zrealizowana SCCLP składająca się $\mathrm{z}$ tylko jednego CCLP. Jest to jednak rzadka sytuacja ponieważ $k$-ty, $(k=1,2, \ldots, a)$ pilot zazwyczaj realizuje więcej niż jeden CCLP podczas zmiany lotnej. 
Models of airmen's aviation activities cycles in the tactical aircraft's operating... Modele cykli czynności lotniczych pilotów w systemie użytkowania samolotów...

Ponadto proces $\mathrm{S} 2$ jest przeprowadzany $\mathrm{z}$ udziałem każdego pilota z BLT/GDL/ELT realizującego pojedyncze CCLP podczas zmiany lotnej. Proces S2 jest przeprowadzany tylko w ramach SCCLP realizowanych na podstawie planowej tabeli lotów i jest pomijany w przypadku gdy SCCLP realizowane są na podstawie rozkazu(-ów) organizatora lotów. Każdy $\mathrm{z}$ trzech wskazanych tu rodzajów podsumowań misji lotniczych jest szczegółowo opisany w [6].

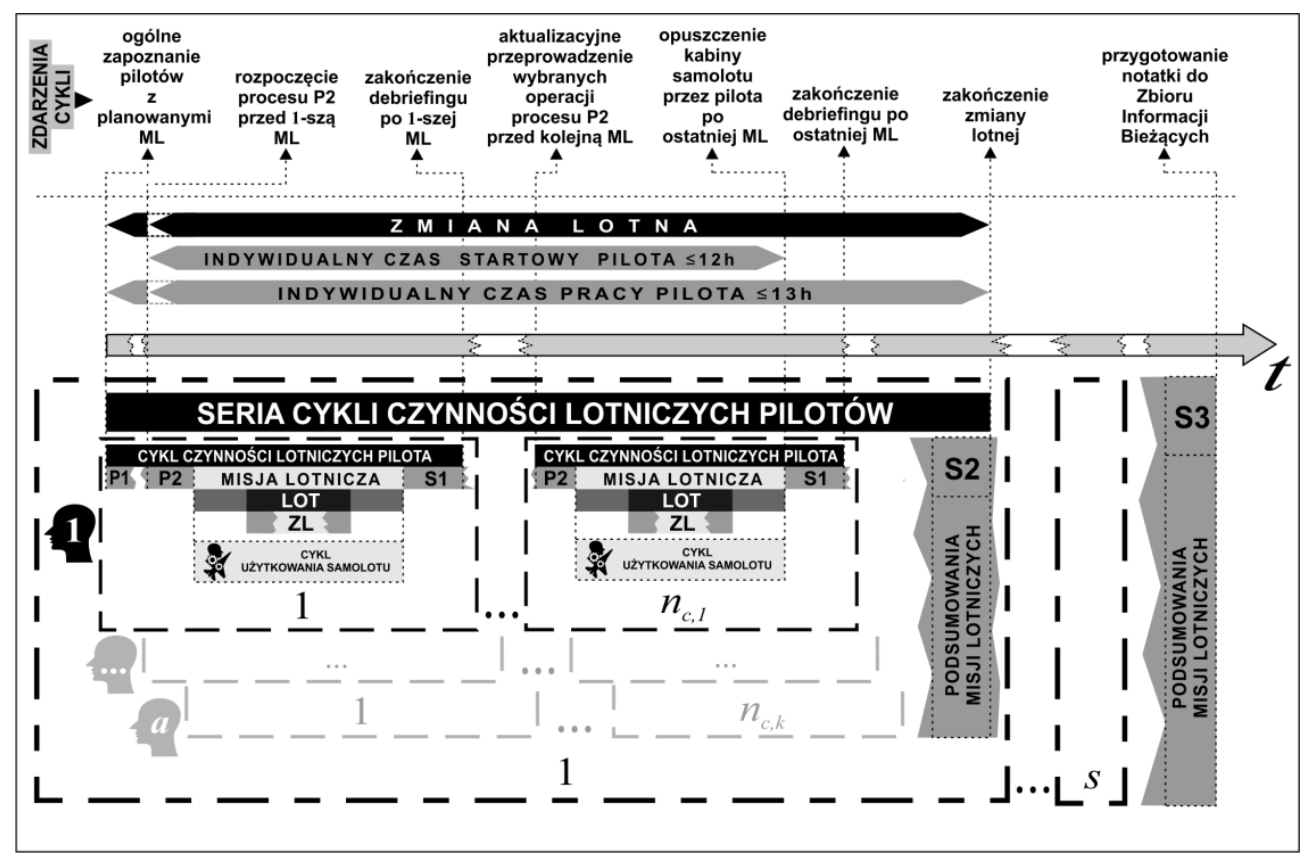

Rys. 6 Model serii cykli czynności lotniczych pilotów w SUżSLT

(objaśnienia użytych skrótów i zmiennych znajduja się w tekście)

Podsumowanie bieżące jest obowiązkową częścią pojedynczego CCLP, warunkującą rozpoczęcie każdego kolejnego CCLP. W wyniku przeprowadzanego $\mathrm{w}$ procesie S1 debriefingu wypracowywane są wnioski i zalecenia, które bezwzględnie należy uwzględnić w czasie realizacji kolejnego CCLP już w jego części przygotowawczej (procesy P1 i P2).

Po zrealizowaniu przez $k$-tego pilota pierwszego CCLP, nie realizuje on już ponownie procesu P1 na początku kolejnego CCLP z jego udziałem w ramach tej samej zmiany lotnej. Realizowane są natomiast wybrane operacje procesu P2, które mają głównie charakter aktualizacyjny wodniesieniu do procesu P2 przeprowadzonego $w$ ramach pierwszego CCLP tego pilota $w$ ramach zmiany lotnej. Taka sytuacja ma miejsce w każdym kolejnym CCLP od drugiego do $n_{c, k}$-tego, a realizowanych przez $k$-tego pilota. Kilka cykli czynności lotniczych pilota/pilotów, stanowi jeden SCCLP, która kończy się procesem S2 zamykającym zmianę lotną. 
Zmiana lotna w prezentowanych tu rozważaniach odpowiada SCCLP i często bywa określana również mianem dnia lotnego. Jednak określenie zmiana lotna wydaje się być trafniejszym, ze względu na możliwość realizacji SCCLP w różnych częściach doby.

Proces S3 jest realizowany po zakończeniu $s$-tej SCCLP, jednak nie rzadziej niż raz w miesiącu. Ten rodzaj podsumowania dotyczy wszystkich SCCLP zrealizowanych w danym okresie czasu i kończy się przygotowaniem notatki do Zbioru Informacji Bieżących [6]. W procesie S3 nie biorą udziału wszyscy piloci, a zazwyczaj tylko osoby funkcyjne z klucza lotniczego, ELT, GDL, BLT [1, 8].

Zmiana lotna składa się zazwyczaj $\mathrm{z}$ więcej niż jednego CCLP, które mogą obejmować więcej niż jedną i do tego różne misje lotnicze. W SUżSLT od chwili rozpoczęcia procesu $\mathrm{P} 2 \mathrm{w}$ pierwszym CCLP $k$-tego $(k=1,2, \ldots, a)$ pilota podczas zmiany lotnej, do momentu opuszczenia kabiny samolotu po misji lotniczej w $n_{c, k}$ tym CCLP, liczy się indywidualny czas startowy $k$-tego pilota. Indywidualny czas startowy $k$-tego pilota może trwać maksymalnie 12 godzin (z uwzględnieniem określonych $\mathrm{w}$ [4] zastrzeżeń), przy zachowaniu indywidualnego czasu pracy $k$-tego pilota, który nie może przekraczać wymiaru 13 godzin. W ramach indywidualnego czasu startowego określone są również: maksymalny nalot $k$-tego pilota, maksymalna liczba misji lotniczych jaką może $k$-ty pilot wykonać, przerwy między kolejnymi misjami lotniczymi i CCLP. Wymienione aspekty są regulowane przez [4] oraz programy szkolenia lotniczego. Zgodnie z [4] przerwy pomiędzy kolejnymi indywidualnymi czasami startowymi powinny zapewniać wymagany czas odpoczynku. Czas odpoczynku należy przy tym rozumieć jako czas wolny od zajęć służbowych, pomiędzy kolejnymi okresami indywidualnego czasu startowego $k$-tego pilota lub kolejnymi okresami wykonywania czynności służbowych. W przypadku pilota realizującego czynności operatora w SUżSLT w ramach SCCLP, minimalny czas odpoczynku wynosi 11 godzin.

\section{Podsumowanie}

Odejście od często spotykanego utożsamiania określeń „misja lotnicza”, „lot” oraz „zadanie lotnicze”, daje możliwość klarownego i koherentnego opracowania zbioru podstawowych pojęć związanych z użytkowaniem samolotów lotnictwa taktycznego.

Misja lotnicza jest to główna część cyklu czynności lotniczych pilota obejmująca szereg następujących po sobie w określonej kolejności procesów, operacji i zdarzeń od momentu zdarzenia przyjęcia samolotu przez pilota do momentu zdarzenia opuszczenia kabiny samolotu przez pilota. Często dochodzi do sytuacji, kiedy ta sama misja lotnicza jest realizowana jednocześnie przez kilku pilotów będących operatorami kilku samolotów tworzących ugrupowanie/formację. 
Models of airmen's aviation activities cycles in the tactical aircraft's operating... Modele cykli czynności lotniczych pilotów w systemie użytkowania samolotów...

Taka sytuacja wynika zazwyczaj ze złożoności planowanej misji lotniczej na którą składa się wymóg jednoczesnej realizacji kilku lotów celem wykonania tego samego lub różnych zadań lotniczych.

Lot jest to etap misji lotniczej obejmujący ruch samolotu w przestrzeni powietrznej od momentu zdarzenia jego oderwania się od powierzchni drogi startowej do momentu zdarzenia jego przyziemienia (ponownego zetknięcia $\mathrm{z}$ ziemią) na powierzchni drogi startowej.

Zadanie lotnicze jest główną fazą lotu i stanowi zespół określonych, docelowych działań pilota/pilotów podczas lotu w wyznaczonym terminie i obszarze, realizowanych dla osiągnięcia założonych celów misji lotniczej takich jak m.in.: szkoleniowe, treningowe, operacyjne lub bojowe. Określane jest przez przełożonego, instruktora lub lidera ugrupowania/formacji i realizowane przez pilota jako operatora z użyciem samolotu w SUżSLT.

Przedstawione modele oprócz usystematyzowania pojęciowego spełniają zadanie uporządkowania w czasie kolejnych części, etapów i faz w CCLP oraz SCCLP realizowanych w SUżSLT. Wskazują także pośrednio na okresy, w których realizowane są procesy związane $\mathrm{z}$ utrzymaniem samolotów. Zaprezentowane w tej pracy podejście dotyczy lotnictwa taktycznego funkcjonującego w czasie pokoju.

Podziękowania

Praca finansowana ze środków finansowych na działalność statutowa Wydziatu Maszyn Roboczych i Transportu Politechniki Poznańskiej nr 05/52/DSPB/0280.

\section{Literatura}

[1] Augustyn E., Kadziński A., Systemic approach and model of the Polish Tactical Air Force. Journal of KONES Powertrain and Transport, nr 24(2), 2017, p. 7-16, DOI: 10.5604/01.3001.0010.2889.

[2] Augustyn E., Kadziński A., Model of Generalized Technical System. Journal of Mechanical and Transport Engineering, nr 69(3), 2017, p. 5-13, DOI: 10.21008/j.2449-920X.2017.69.3.01.

[3] Borgoń J., Jaźwinski J., Niezawodnośc eksploatacyjna i bezpieczeństwo lotów, Wydawnictwo Komunikacji i Łączności, Warszawa 1989.

[4] Dowództwo Generalne Rodzajów Sił Zbrojnych (MON), Regulamin lotów lotnictwa Sił Zbrojnych Rzeczypospolitej Polskiej (RL-2016), Warszawa 2016.

[5] Dowództwo Generalne Rodzajów Sił Zbrojnych (MON), Instrukcja służby inżynieryjno-lotniczej lotnictwa Sił Zbrojnych Rzeczypospolitej Polskiej (ISIL-2017), Warszawa 2017. 
[6] Dowództwo Generalne Rodzajów Sił Zbrojnych (MON), Instrukcja organizacji lotów w lotnictwie Sił Zbrojnych Rzeczypozpolitej Polskiej (IOL2016), Warszawa 2016.

[7] Dowództwo Generalne Rodzajów Sił Zbrojnych (MON), Instrukcja zarządzania ruchem lotniczym w Siłach Zbrojnych Rzeczypospolitej Polskiej (IZRL-2017), Warszawa 2017.

[8] Grenda B., Mróz P., Nowak J., Sławiński M., Dowodzenie siłami powietrznymi, Akademia Obrony Narodowej, Warszawa 2011.

[9] International Civil Aviation Organization, International Standards. Annex 2 to the Convention on International Civil Aviation - Rules of the Air, 10th edition, 2005.

[10] International Civil Aviation Organization, International Standards and Recommended Practices. Annex 8 to the Convention on International Civil Aviation - Airworthiness of Aircraft, 11th edition, 2010.

[11] International Civil Aviation Organization, International Standards and Recommended Practices. Annex 14 to the Convention on International Civil Aviation - Aerodromes, vol.1. Aerodrome Design and Operations, 5th edition, 2009.

[12] International Civil Aviation Organization, Procedures of Air Navigation Services . Aircraft Operations (Doc 8168), vol. 1. Flight Procedures, 5th edition, 2006.

[13] Lewitowicz J., Eksploatacyjne własności i własciwości samolotów i śmigłowców, Instytut Techniczny Wojsk Lotniczych, Warszawa 2015.

[14] Lewitowicz J., Podstawy esploatacji statków powietrznych. Tom 1. Statek powietrzny i elementy teorii, Instytut Techniczny Wojsk Lotniczych, Warszawa 2001.

[15] Lewitowicz J., Podstawy eksploatacji statków powietrznych. Tom 3. Systemy eksploatacji statków powietrznych, Instytut Techniczny Wojsk Lotniczych, Warszawa 2006.

[16] Lewitowicz J., Żyluk A., Podstawy eksploatacji statków powietrznych. Tom 5. Techniczna eksploatacja statków powietrznych, Instytut Techniczny Wojsk Lotniczych, Warszawa 2009.

[17] Milkiewicz A., Praktyczna aerodynamika i mechanika lotu samolotu odrzutowego w tym wysokomanewrowego, Instytut Techniczny Wojsk Lotniczych, Warszawa 2009.

[18] Młyńczak M., Metodyka badań eksploatacyjnych obiektów mechanicznych, Oficyna Wydawnicza Politechniki Wrocławskiej, Wrocław 2012.

[19] NATO Standarization Agency, NATO Glossary of Terms and Definitions (AAP-6), Brussels 2014.

[20] Sobol E. (red.), Słownik wyrazów obcych. Wydanie nowe, Wydawnictwo Naukowe PWN, Warszawa 1999. 
Models of airmen's aviation activities cycles in the tactical aircraft's operating... Modele cykli czynności lotniczych pilotów w systemie użytkowania samolotów...

[21] United States Air Force - Air Education and Training Command, AETC Tactics Techniques and Procedures 11-1 (AETCTTP 11-1). Employment Fundamentals T-38C - Introduction to Fighter Fundamentals (IFF), 2009.

[22] United States of America - Department of the Air Force, Air Force Manual 11-217, vol. 2 (AFMAN 11-217V2). Flying Operations - Visual Flight Procedures, 2010.

[23] United States of America - Department of the Air Force, Air Force Manual 11-248, (AFMAN 11-248). Flying Operations - T6 Primary Flying, 2011.

[24] Zabłocki E., Siły powietrzne, Akademia Obrony Narodowej, Warszawa 2007.

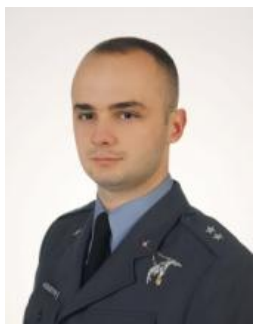

Emil Augustyn, doktorant Politechniki Poznańskiej, Wydziat Maszyn Roboczych i Transportu, absolwent Wyższej Szkoty Oficerskiej Sit Powietrznych - promocja 2015, specjalizacja naukowa: transport, niezawodność wojskowych statków powietrznych, bezpieczeństwo oraz analiza ryzyka zagrożeń w lotnictwie wojskowym, modelowanie $i$ analiza procesów oraz systemów w transporcie (Udziat 60\%).

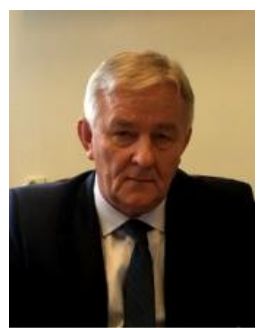

prof. Adam Kadziński, Politechnika Poznańska, Instytut Silników Spalinowych $i$ Transportu, specjalizacja naukowa: transport, niezawodność pojazdów kolejowych, bezpieczeństwo $w$ transporcie kolejowym, zarzadzanie ryzykiem $w$ transporcie, modelowanie $i$ analiza procesów oraz systemów $w$ transporcie (Udziat 40\%). 